\title{
QSAR APPROACH AND SYNTHESIS OF CHALCONE DERIVATIVES AS ANTIMALARIAL COMPOUND AGAINST Plasmodium Falciparum 3D7 Strain
}

\author{
S. S. W. Waskitha, F. E. Mulyana, N. F. Riza, Y. M. Stansyah, I. Tahir \\ and T. D. Wahyuningsih ${ }^{\bowtie}$ \\ Department of Chemistry, Faculty of Mathematics and Natural Sciences, \\ Universitas Gadjah Mada, Sekip Utara BLS 21, Yogyakarta-55281, Indonesia \\ Corresponding Author: tutikdw@ugm.ac.id
}

\begin{abstract}
A quantitative structure-activity relationship (QSAR) analysis of serial chalcone derivatives as antimalarial agents against Plasmodium falciparum strain 3D7 (Pf3D7) was conducted, it was then used to predict the activity of several synthesized chalcones. The QSAR analysis was performed using stepwise multiple linear regression, and the results showed that the antimalarial activity of chalcone derivatives had a strong correlation towards electronic and molecular descriptors. The best QSAR model was used for designing 3 chalcone derivatives which were further synthesized, characterized, and tested as an antimalarial agent. This study revealed that (E)-3-(4-methoxyphenyl)-1-(2,4dimethoxyphenyl) prop-2-en-1-one had an excellent activity as an antimalarial agent with an $\mathrm{IC}_{50}$ value of $1.29 \mu \mathrm{M}$. Molecular docking results showed that it interacted nicely on the PfDHODH active site.

Keywords: Chalcone, QSAR Approach, Antimalarial Agent, Claisen-Schmidt Condensation, Molecular Docking
\end{abstract}

RASĀYAN J. Chem., Vol. 14, No.4, 2021

\section{INTRODUCTION}

Malaria is an endemic disease caused by Plasmodium parasites. Among many Plasmodium parasites, Plasmodium falciparum is the deadliest malaria parasite. ${ }^{1}$ The World Health Organization (WHO) in 2017 reported that there were 219 million cases and 435 deaths caused by malarial symptoms. ${ }^{2}$ However, in other studies, the resistance of antimalarial agents has been an exclusive problem with $P$. falciparum, which is resistant to chloroquine. ${ }^{3}$ Therefore, it is necessary to find novel antimalarials that can overcome drug resistance. Chalcones are natural products that belong to the flavonoid family, which have a wide range of biological properties such as anticancer ${ }^{4}$ and antimalaria. ${ }^{5}$ Suma et al. synthesized some chalcone derivatives via Claisen Schmidt condensation ${ }^{6}$, and it has also been reported that functional groups modification and design of chalcone derivatives can affect its antimalarial activity. ${ }^{7}$ One method which could be used for designing new compounds with better biological activity than its lead compound is Quantitative Structure-Activity Relationship (QSAR). Several studies have been conducted to determine QSAR descriptors using the Density Functional Theory (DFT) by computational method. ${ }^{8,9}$ Another computational method, such as molecular docking, could give information about the interaction and stability of drugs and their target. Other studies have been carried out to improve the activity of novel antimalarial agents by targeting Plasmodium falciparum dihydroorotate dehydrogenase (PfDHODH) enzyme as its specific target. ${ }^{10,11}$ Recently, Ibrahim et al. designed some indolyl-3-ethanone- $\alpha$-thioethers derivatives as antimalarial agents based on the QSAR approach and molecular docking targeting PfDHODH. ${ }^{12}$ However, there is still no comprehensive study regarding the design of chalcone-based antimalarial agents based on QSAR approach and molecular docking study targeting PfDHODH. This research aimed to design some chalcone derivatives based on QSAR approaches and then evaluate them as antimalarial agents targeting $P$. falciparum 3D7 strain. Furthermore, all designed chalcone derivatives were docked against PfDHODH to evaluate their mechanism of action as antimalarial agents. 
RASĀYAN J. Chem.

Vol. 14 | No. 4 |2363-2370| October- December | 2021

QSAR Data Set

\section{EXPERIMENTAL}

A total of 27 chalcone derivatives was taken from the literature ${ }^{7}$ (Table-1). The inhibition concentration $\left(\mathrm{IC}_{50}\right)$ values were converted to $\mathrm{pIC}_{50}\left(\log \frac{1}{I C_{50}(M)}\right)$ and the antimalarial activity could be categorized into five groups which are inactive $\left(\mathrm{IC}_{50}>200 \mu \mathrm{M}\right)$; low $\left(\mathrm{IC}_{50} 100-200 \mu \mathrm{M}\right)$; moderate $\left(\mathrm{IC}_{50} 20-100 \mu \mathrm{M}\right)$; good $\left(\mathrm{IC}_{50} 1-20 \mu \mathrm{M}\right)$; and excellent $\left(\mathrm{IC}_{50}<1 \mu \mathrm{M}\right){ }^{13}$

Table-1: Chalcone Derivatives Data Set and Their Antimalarial Activity ${ }^{7}$

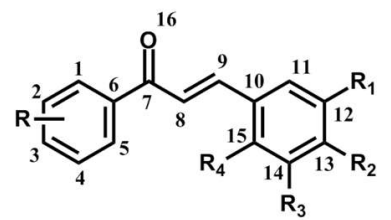

\begin{tabular}{|c|c|c|c|c|c|c|c|c|}
\hline Comp. & $\mathrm{R}$ & $\mathrm{R}_{1}$ & $\mathrm{R}_{2}$ & $\mathrm{R}_{3}$ & $\mathrm{R}_{4}$ & $\begin{array}{l}\mathrm{IC}_{50} \\
(\mu \mathrm{M})\end{array}$ & $\mathrm{pIC}_{50}$ & $\begin{array}{c}\text { Antimalarial } \\
\text { Activity }\end{array}$ \\
\hline 1 & $4-\mathrm{OH}$ & Allyl & $\mathrm{OH}$ & $\mathrm{OCH}_{3}$ & $\mathrm{H}$ & 38.5 & 4.414 & Moderate \\
\hline 2 & $4-\mathrm{Cl}$ & Allyl & $\mathrm{OH}$ & $\mathrm{OCH}_{3}$ & $\mathrm{H}$ & 28.0 & 4.552 & Moderate \\
\hline $3^{\mathrm{a}}$ & $4-\mathrm{Cl}$ & Allyl & $\mathrm{OCH}_{3}$ & $\mathrm{OCH}_{3}$ & $\mathrm{H}$ & 3.9 & 5.408 & Good \\
\hline 4 & $4-\mathrm{OCH}_{3}$ & Allyl & $\mathrm{OCH}_{3}$ & $\mathrm{OCH}_{3}$ & $\mathrm{H}$ & 4.3 & 5.366 & Good \\
\hline 5 & $3,4-\mathrm{OCH}_{2} \mathrm{O}-$ & Allyl & $\mathrm{OCH}_{3}$ & $\mathrm{OCH}_{3}$ & $\mathrm{H}$ & 4.7 & 5.327 & Good \\
\hline 6 & $4-\mathrm{Br}$ & Allyl & $\mathrm{OCH}_{3}$ & $\mathrm{OCH}_{3}$ & $\mathrm{H}$ & 5.3 & 5.275 & Good \\
\hline 7 & $4-\mathrm{NO}_{2}$ & Allyl & $\mathrm{OCH}_{3}$ & $\mathrm{OCH}_{3}$ & $\mathrm{H}$ & 12.5 & 4.903 & Good \\
\hline 8 & $4-\mathrm{Cl}$ & Allyl & O-Allyl & $\mathrm{OCH}_{3}$ & $\mathrm{H}$ & 7.8 & 5.107 & Good \\
\hline $9^{a}$ & 3,4-diCl & $\mathrm{H}$ & O-Allyl & $\mathrm{OCH}_{3}$ & $\mathrm{H}$ & 10.0 & 5.000 & Good \\
\hline 10 & $4-\mathrm{Br}$ & $\mathrm{H}$ & O-Allyl & $\mathrm{OCH}_{3}$ & $\mathrm{H}$ & 8.1 & 5.091 & Good \\
\hline 11 & $4-\mathrm{F}$ & $\mathrm{H}$ & O-Allyl & $\mathrm{OCH}_{3}$ & $\mathrm{H}$ & 23.0 & 4.638 & Moderate \\
\hline 12 & $3-\mathrm{Cl}$ & $\mathrm{H}$ & O-Allyl & $\mathrm{OCH}_{3}$ & $\mathrm{H}$ & 5.3 & 5.275 & Good \\
\hline 13 & $4-\mathrm{OCH}_{3}$ & $\mathrm{H}$ & O-Allyl & $\mathrm{OCH}_{3}$ & $\mathrm{H}$ & 22.5 & 4.647 & Moderate \\
\hline 14 & $3,4-\mathrm{OCH}_{2} \mathrm{O}-$ & $\mathrm{H}$ & O-Allyl & $\mathrm{OCH}_{3}$ & $\mathrm{H}$ & 38.5 & 4.414 & Moderate \\
\hline 15 & 4-NH ${ }_{2}$ & $\mathrm{H}$ & O-Allyl & $\mathrm{OCH}_{3}$ & $\mathrm{H}$ & 36.0 & 4.443 & Moderate \\
\hline 16 & $\mathrm{H}$ & $\mathrm{H}$ & O-Allyl & $\mathrm{OCH}_{3}$ & $\mathrm{H}$ & 38.0 & 4.420 & Moderate \\
\hline 17 & 4-O-Allyl & $\mathrm{H}$ & O-Allyl & $\mathrm{OCH}_{3}$ & $\mathrm{H}$ & 7.4 & 5.130 & Good \\
\hline 18 & $4-\mathrm{Cl}$ & $\mathrm{H}$ & $\mathrm{H}$ & $\mathrm{OCH}_{3}$ & O-Allyl & 12.5 & 4.903 & Good \\
\hline $19^{\mathrm{a}}$ & $4-\mathrm{Cl}$ & $\mathrm{H}$ & $\mathrm{OCH}_{3}$ & O-Allyl & $\mathrm{H}$ & 18.0 & 4.744 & Good \\
\hline 20 & $4-\mathrm{Cl}$ & $\mathrm{H}$ & $\mathrm{OH}$ & $\mathrm{OCH}_{3}$ & $\mathrm{H}$ & 28.0 & 4.552 & Moderate \\
\hline 21 & $4-\mathrm{Cl}$ & $\mathrm{H}$ & O-Butyl & $\mathrm{OCH}_{3}$ & $\mathrm{H}$ & 14.8 & 4.829 & Good \\
\hline 22 & $4-\mathrm{Cl}$ & $\mathrm{H}$ & $\begin{array}{l}\mathrm{O}-\mathrm{CH}_{2-} \\
\mathrm{Ph}-4-\mathrm{Br}\end{array}$ & $\mathrm{OCH}_{3}$ & $\mathrm{H}$ & 8.0 & 5.096 & Good \\
\hline 23 & $4-\mathrm{Cl}$ & $\mathrm{O}-\mathrm{CH}_{3}$ & O-Allyl & $\mathrm{OCH}_{3}$ & $\mathrm{H}$ & 3.8 & 5.420 & Good \\
\hline 24 & $4-\mathrm{Cl}$ & $\mathrm{H}$ & O-Allyl & $\mathrm{H}$ & $\mathrm{H}$ & 43.0 & 4.366 & Moderate \\
\hline $25^{\mathrm{a}}$ & $4-\mathrm{Cl}$ & $\mathrm{H}$ & $\mathrm{H}$ & $\mathrm{H}$ & O-Allyl & 9.0 & 5.045 & Good \\
\hline 26 & $4-\mathrm{Cl}$ & $\mathrm{H}$ & O-Allyl & $\mathrm{O}-\mathrm{C}_{2} \mathrm{H}_{5}$ & $\mathrm{H}$ & 28.0 & 4.552 & Moderate \\
\hline $27^{\mathrm{a}}$ & $\begin{array}{l}\text { 3-O-Allyl } \\
\text { 4-OCH}\end{array}$ & $\mathrm{H}$ & $\mathrm{Cl}$ & $\mathrm{H}$ & $\mathrm{H}$ & 8.6 & 5.065 & Good \\
\hline
\end{tabular}

$\left.{ }^{a}\right)$ compound test set

\section{QSAR Analysis}

The geometry optimization of 27 chalcone derivatives and quantum descriptors calculations were conducted using DFT/B3LYP with a 6-31G basis set using Gaussian $09^{14}$, whereas molecular descriptors were calculated using HyperChem. ${ }^{15}$ The quantum descriptors were net atomic charges on chalcone derivatives structure, HOMO energy (E_HOMO), and LUMO energy (E_LUMO). Whereas molecular descriptors were molecular volume (VOL), polarizability (POL), surface area (SA), molar refractivity (MR), $\log \mathrm{P}$, and molecular weight (MW) ${ }^{8}$ Correlation models of QSAR were evaluated using multiple linear regression analysis by employing BuildQSAR software with $\mathrm{pIC}_{50}$ as dependent variables and 
descriptors as independent variables. In multiple linear regression analysis using BuildQSAR software, descriptors that are not significantly correlated to $\mathrm{pIC}_{50}$ were removed to get better equation. ${ }^{8,16}$ All of the descriptors were given in supplementary files. The best QSAR model was selected according to its statistical parameters of internal validation and external validation. Internal validation parameters were $\mathrm{r}^{2}$ value, standard error of estimate (SEE), $\mathrm{F}_{\mathrm{cal}} / \mathrm{F}_{\mathrm{tab}}$, and predicted residual error sum of squares (PRESS), whereas external validation statistical parameters were also $r^{2}$ value, PRESS, and $r_{m}^{2} \cdot{ }^{17}$ This QSAR equation was used to predict the antimalarial activity of several new hypothetic chalcone derivatives.

\section{Materials}

All materials used for chalcone synthesis were originated from E. Merck with pro analysis grade and used without further purification, i.e., $p$-anisaldehyde, acetophenone, 4-hydroxyacetophenone, 2,4dimethoxyacetophenone, potassium hydroxide, sodium hydroxide, ethanol, methanol, hydrochloric acid $37 \%$, dichloromethane, $n$-hexane, and ethyl acetate. Materials used for the antimalarial activity assay were P. falciparum 3D7 strain, Red Blood Cells (RBC), immersion oil, methanol, sorbitol, Roswell Park Memorial Institute (RPMI) medium, Hydroxyethylpiperazine (HEPES), gentamycin, serum 10\%, and Giemsa $10 \%$.

\section{Instrumentations}

Melting points were recorded by a digital melting point apparatus on Electrothermal 9100 and uncorrected. Thin-layer chromatography (TLC) was performed on pre-coated silica gel plates. Mass spectra were obtained from GC-MS spectrometer (Shimadzu QP2010S). Infrared spectra were recorded on Shimadzu Prestige-21 (KBr). ${ }^{1} \mathrm{H}$ and ${ }^{13} \mathrm{C}-\mathrm{NMR}$ characterizations were carried out on JEOL JNM-ECA $\left(500 \mathrm{MHz}\left({ }^{1} \mathrm{H}\right)\right.$ and $\left.125 \mathrm{MHz}\left({ }^{13} \mathrm{C}\right)\right)$ using tetramethylsilane (TMS) as an internal standard. The equipment used for the antimalarial test were microplate 96 well with Lid (Iwaki), centrifuge (SORVALL MC 12V), Ultrasonic Generator (42 kHz, Krisbow), Elisa Reader (BioRad Benchmark), $\mathrm{CO}_{2}$ incubator, laminar airflow cabinet (Esco Class II BSC), autoclave, object-glass, and inverted microscope.

\section{Synthesis of (E)-3-(4-methoxyphenyl)-1-phenyl prop-2-en-1-one (Chalcone A)}

Acetophenone $(0.61 \mathrm{~g}, 5 \mathrm{mmol})$ was diluted in methanol $(5 \mathrm{~mL})$, then $15 \% \mathrm{KOH}(10 \mathrm{~mL})$ and $\mathrm{p}$ anisaldehyde $(0.61 \mathrm{~mL}, 5 \mathrm{mmol})$ were added dropwise. The mixture was irradiated for $1.5 \mathrm{~h}$ by an ultrasonic generator. The mixture was neutralized using $\mathrm{HCl} 10 \%$; the precipitates were washed with distilled water and dried inside a vacuum desiccator. The solid product was recrystallized with ethanol to give chalcone $\mathbf{A}$ (0.96 g, 80.67\%) as yellow solid. m.p 67-69 ${ }^{\circ} \mathrm{C}$. IR $\left(\mathrm{KBr}, \mathrm{cm}^{-1}\right): 1658(\mathrm{C}=\mathrm{O}), 1597$ and $1512(\mathrm{C}=\mathrm{C} \mathrm{Ar})$, 1265 (C-O-C), $987\left(\mathrm{C}=\mathrm{C}\right.$ trans). ${ }^{1} \mathrm{H}-\mathrm{NMR}\left(500 \mathrm{MHz}, \mathrm{CDCl}_{3}\right) \delta(\mathrm{ppm}): 3.86\left(3 \mathrm{H}, \mathrm{s}, \mathrm{OCH}_{3}\right), 6.94(2 \mathrm{H}, \mathrm{d}, J$ $\left.8.4 \mathrm{~Hz}, \mathrm{H}_{\mathrm{Ar}-\mathrm{B}}\right), 7.42\left(1 \mathrm{H}, \mathrm{d}, J 15.6 \mathrm{~Hz},=\mathrm{CH}_{\alpha}\right), 7.50\left(2 \mathrm{H}, \mathrm{t}, \mathrm{H}_{\mathrm{Ar}-\mathrm{B}}\right), 7.59\left(3 \mathrm{H}, \mathrm{dd}, J 7.8,8.5 \mathrm{~Hz}, \mathrm{H}_{\mathrm{Ar}-\mathrm{A}}\right), 7.79$ $\left(1 \mathrm{H}, \mathrm{d}, J 15.6 \mathrm{~Hz},=\mathrm{CH}_{\beta}\right), 8.01\left(2 \mathrm{H}, \mathrm{d}, \mathrm{J} 8.4 \mathrm{~Hz}, \mathrm{H}_{\mathrm{Ar}-\mathrm{A}}\right) .{ }^{13} \mathrm{C}-\mathrm{NMR}\left(125 \mathrm{MHz}, \mathrm{CDCl}_{3}\right) \delta(\mathrm{ppm}): 55.6\left(\mathrm{OCH}_{3}\right)$, 114.6, $120.0\left(=\mathrm{CH}_{\alpha}\right), 127.8,128.6,128.7,130.4,132.7,138.7,144.9\left(=\mathrm{CH}_{\beta}\right), 161.9,190.8(\mathrm{C}=\mathrm{O})$. Mass spectrum (EI): m/z $238\left(\mathrm{M}^{+}\right), 207,161,133,108,77$ (base peak), 51.

\section{Synthesis of (E)-3-(4-methoxyphenyl)-1-(4-hydroxyphenyl) prop-2-en-1-one (Chalcone B)}

This was prepared as described for chalcone $\mathbf{A}$ from 4-hydroxyacetophenone $(0.68 \mathrm{~g}, 5 \mathrm{mmol})$ in methanol, $40 \% \mathrm{KOH}(15 \mathrm{~mL})$ and $\mathrm{p}$-anisaldehyde $(0.61 \mathrm{~mL}, 5 \mathrm{mmol})$ to give chalcone $\mathbf{B}(0.92 \mathrm{~g}, 72.38 \%)$ as yellow solid. m.p 188-190 ${ }^{\circ} \mathrm{C}$. IR $\left(\mathrm{KBr}, \mathrm{cm}^{-1}\right): 3132(\mathrm{OH}), 1643(\mathrm{C}=\mathrm{O}), 1597$ and $1512(\mathrm{C}=\mathrm{C} \mathrm{Ar}), 1219(\mathrm{C}-\mathrm{O}-\mathrm{C})$, $995\left(\mathrm{C}=\mathrm{C}\right.$ trans). ${ }^{1} \mathrm{H}-\mathrm{NMR}\left(500 \mathrm{MHz}, \mathrm{CDCl}_{3}\right) \delta(\mathrm{ppm}): 3.80\left(3 \mathrm{H}, \mathrm{s}, \mathrm{OCH}_{3}\right), 6.89\left(2 \mathrm{H}, \mathrm{d}, J 8.40 \mathrm{~Hz}, \mathrm{H}_{\mathrm{Ar}-\mathrm{A}}\right)$, $6.99\left(2 \mathrm{H}, \mathrm{d}, J 9.10 \mathrm{~Hz}, \mathrm{H}_{\mathrm{Ar}-\mathrm{B}}\right), 7.64\left(1 \mathrm{H}, \mathrm{d}, J 15.50 \mathrm{~Hz},=\mathrm{CH}_{\alpha}\right), 7.75\left(1 \mathrm{H}, \mathrm{d}, J 15.60 \mathrm{~Hz},=\mathrm{CH}_{\beta}\right), 7.80(2 \mathrm{H}$, $\left.\mathrm{d}, J 8.45 \mathrm{~Hz}, \mathrm{H}_{\mathrm{Ar}-\mathrm{B}}\right), 8.04\left(2 \mathrm{H}, \mathrm{d}, J 8.40 \mathrm{~Hz}, \mathrm{H}_{\mathrm{Ar}-\mathrm{A}}\right) .{ }^{13} \mathrm{C}-\mathrm{NMR}\left(125 \mathrm{MHz}, \mathrm{CDCl}_{3}\right) \delta(\mathrm{ppm}): 55.6\left(\mathrm{OCH}_{3}\right)$, 114.6, 115.6, $119.7\left(=\mathrm{CH}_{\alpha}\right), 127.7,129.5,130.8,131.4,143.0\left(=\mathrm{CH}_{\beta}\right), 161.4,162.2,187.4(\mathrm{C}=\mathrm{O})$. Mass spectrum (EI): m/z $254\left(\mathrm{M}^{+}\right), 239,211,161,121,108,93,77,65$ (base peak), 39.

\section{Synthesis of (E)-3-(4-methoxyphenyl)-1-(2,4-dimethoxyphenyl) prop-2-en-1-one (Chalcone C)}

This was prepared as described for chalcone A from 2,4-dimethoxyacetophenone $(0.54 \mathrm{~g}, 3 \mathrm{mmol})$ in methanol, $20 \% \mathrm{NaOH}(5 \mathrm{~mL})$ and p-anisaldehyde $(0.36 \mathrm{~mL}, 3 \mathrm{mmol})$ and the mixture was stirred at room temperature for $24 \mathrm{~h}$. After working up, the product was recrystallized from ethanol to give chalcone $\mathbf{C}$ 
$(0.78 \mathrm{~g}, 86.70 \%)$ as a yellow solid. m.p 86-87 ${ }^{\circ} \mathrm{C} . \mathrm{IR}\left(\mathrm{KBr}, \mathrm{cm}^{-1}\right): 1643(\mathrm{C}=\mathrm{O}), 1605(\mathrm{C}=\mathrm{C}$ alkene $), 1582$ $\left(\mathrm{C}=\mathrm{C}\right.$ Ar), 1250 (C-O-C), 980 (C-H trans). ${ }^{1} \mathrm{H}-\mathrm{NMR}\left(500 \mathrm{MHz}, \mathrm{CDCl}_{3}\right) \delta(\mathrm{ppm}): 3.84\left(3 \mathrm{H}, \mathrm{s}, \mathrm{OCH}_{3}\right), 3.87$ $\left(3 \mathrm{H}, \mathrm{s}, \mathrm{OCH}_{3}\right), 3.90\left(3 \mathrm{H}, \mathrm{s}, \mathrm{OCH}_{3}\right), 6.50\left(1 \mathrm{H}, \mathrm{d}, J 2.0 \mathrm{~Hz}, \mathrm{H}_{\mathrm{Ar}-\mathrm{A}}\right), 6.56\left(1 \mathrm{H}, \mathrm{dd}, J 2.0,9.0 \mathrm{~Hz}, \mathrm{H}_{\text {Ar-A }}\right), 6.91$ $\left(2 \mathrm{H}, \mathrm{d}, J 8.6 \mathrm{~Hz}, \mathrm{H}_{\text {Ar-B }}\right), 7.39\left(1 \mathrm{H}, \mathrm{d}, J 16 \mathrm{~Hz},=\mathrm{CH}_{\alpha}\right), 7.55\left(2 \mathrm{H}, \mathrm{d}, J 8.6 \mathrm{~Hz}, \mathrm{H}_{\mathrm{Ar}-\mathrm{B}}\right), 7.65(1 \mathrm{H}, \mathrm{d}, J 16 \mathrm{~Hz}$, $\left.=\mathrm{CH}_{\beta}\right), 7.74\left(1 \mathrm{H}, \mathrm{d}, J 9.0 \mathrm{~Hz}, \mathrm{H}_{\mathrm{Ar}-\mathrm{A}}\right) .{ }^{13} \mathrm{C}-\mathrm{NMR}\left(125 \mathrm{MHz}, \mathrm{CDCl}_{3}\right) \delta(\mathrm{ppm}): 55.5\left(-\mathrm{OCH}_{3}\right), 55.6\left(-\mathrm{OCH}_{3}\right)$, $55.8\left(-\mathrm{OCH}_{3}\right), 98.8,105.2,114.4,122.6\left(=\mathrm{CH}_{\alpha}\right), 125.1,128.3,130.1,132.8,142.2\left(=\mathrm{CH}_{\beta}\right), 160.3,161.3$, 164.1, $190.8(\mathrm{C}=\mathrm{O})$. Mass spectrum (EI): m/z $298\left(\mathrm{M}^{+}\right)$, 283, 165, 135, 121 (base peak), 107, 91, 77.

\section{Antimalarial Assay against $P$. falciparum 3D7 strain}

Antimalarial testing was carried out by dissolving $5 \mathrm{mg}$ of sample in $50 \mu \mathrm{L}$ DMSO (stock concentration solution of $5000 \mu \mathrm{g} / \mathrm{mL})$. Hence, a series of diluted solution $(5,1,0.5,0.1$, and $0.05 \mu \mathrm{g} / \mathrm{mL})$ was prepared from stock solution. The parasite used here was ring-stage parasites adjusted to parasitemia $\pm 1 \%$. A series of tested solutions $(100 \mu \mathrm{L})$ in varying concentrations was taken and poured into a well (96 wells). Then $100 \mu \mathrm{L}$ parasites were added until the concentration was adjusted to $2.5,0.5,0.25,0.05$, and $0.025 \mu \mathrm{g} / \mathrm{mL}$. The assay wells were incubated for $48 \mathrm{~h}$ at $37^{\circ} \mathrm{C}$. Blood smears were made from the cultures, and then the blood smears were stained using Giemsa $10 \%$. The percent inhibition was determined by counting infected erythrocytes for every group of 1000 cells of erythrocytes under a microscope. The $\mathrm{IC}_{50}$ values, the concentration required to inhibit parasite growth by $50 \%$, were determined using linear interpolation from the growth inhibition curves generated for each sample-parasite combination. ${ }^{18}$

\section{Molecular Docking Study}

All designed chalcone derivatives were docked against the receptor, i.e., Plasmodium falciparum dihydroorotate dehydrogenase (PfDHODH) (PDB: 1TV5). The ligand-receptor preparation was performed using Discovery Studio ${ }^{19}$ and Autodock Tools 1.5.6. At the protein-ligand preparation step, all solvent molecules were omitted then hydrogen atoms and Kollman charges were added to the receptor. The grid box size was set to $15 \times 15 \times 15 \AA$ with a grid spacing of $1.00 \AA$ centered to the native ligand, while the exhaustiveness value was set to 100. Redocking against native ligand (inhibitor A26) was also conducted to validate the molecular docking procedure, and the root means square deviation (RMSD) of redocking should be $<2.00 \AA .{ }^{20,21}$ The calculation of RMSD value was performed by PyMOL software without any fitting. ${ }^{22}$ Molecular docking and redocking procedure were carried out using AutoDock Vina. ${ }^{23}$ The docked pose with the lowest binding affinity was chosen as the most appropriate docked conformation.

\section{RESULTS AND DISCUSSION}

Four QSAR equations and their statistical parameters were obtained from multiple linear regression calculation (Table-2). The coefficient of determination $\left(\mathrm{r}^{2}\right)$ of the four QSAR equations obtained exceeded 0.6 , so it could be said that all models have a good correlation towards experimental $\mathrm{pIC}_{50} \cdot{ }^{17} \mathrm{In}$ addition, all of the resulted QSAR models also had the $\mathrm{F}_{\text {cal }} / \mathrm{F}_{\text {tab }}$ values of more than 1 . This value showed that the descriptors on the QSAR equation simultaneously affect the antimalarial activity at a significance level of $95 \%{ }^{17}$. The lower value of SEE indicated that the model has a lower deviation from experimental data. The complete equation of models 1 to 4, respectively, are:

$$
\begin{aligned}
& \mathrm{pIC}_{50}=\quad 0.0125 \times(\mathrm{VOL})-0.147 \times(\mathrm{MR})+0,0115 \times(\mathrm{MW})+1.5481 \times\left(\mathrm{qC}_{12}\right)+35.1286 \times\left(\mathrm{qC}_{10}\right)+- \\
& 0,6037 \\
& \mathrm{pIC}_{50}=0.0082 \times(\mathrm{SA})+0.0122 \times(\mathrm{MW})-0.0709 \times(\mathrm{MR})+22.3351 \times\left(\mathrm{E}_{-} \mathrm{HOMO}\right)+50.389 \times(\mathrm{qC} 10)+ \\
& 1.4152 \times\left(\mathrm{qC}_{12}\right)+3.1403 \\
& \mathrm{pIC}_{50}=0.0129 \times(\mathrm{VOL})-0.155 \times(\mathrm{MR})+0.0123 \times(\mathrm{MW})+1.8001 \times\left(\mathrm{qC}_{12}\right)-0.7814 \times\left(\mathrm{qC}_{2}\right)+ \\
& 44.7523 \times\left(\mathrm{qC}_{10}\right)+45.9206 \times(\mathrm{qC} 8)+4.3202 \\
& \mathrm{pIC}_{50}=0.0108 \times(\mathrm{MW})+0,0089 \times(\mathrm{SA})-0.0685 \times(\mathrm{MR})-8.7472 \times\left(\mathrm{qC}_{6}\right)+41.4389 \times\left(\mathrm{qC}_{10}\right)- \\
& 5.3773 \times\left(\mathrm{qC}_{4}\right)+27.317 \times\left(\mathrm{qC}_{8}\right)+2.0235 \times\left(\mathrm{qC}_{12}\right)+2.0865
\end{aligned}
$$

To choose the best QSAR equation, all of the QSAR models have to be validated externally. External validation was carried out to test the ability of all QSAR models that satisfy the statistical criteria in 
RASĀYAN J. Chem.

Vol. 14 | No. 4 |2363-2370| October- December | 2021

predicting antimalarial activity outside the training set compounds (Table-3). It showed that model 4 had the lowest $r^{2}$ and PRESS. All models are valid due to their $r^{2}$ values of more than 0.6. ${ }^{17}$ Another statistical parameter, such as $\mathrm{r}_{\mathrm{m}}^{2}>0.5$, indicates that the model is acceptable and has a good predictive ability. ${ }^{17}$ However, it showed that only model 2 satisfied these statistical parameters. Therefore, model 2 was selected as the best QSAR equation.

Table-2: Four QSAR Models and Their Statistical Properties

\begin{tabular}{c|c|c|c|c|c|c|c}
\hline Model & Descriptors & $\mathrm{r}$ & $\mathrm{r}^{2}$ & $\mathrm{SEE}$ & $\mathrm{F}$ & $\mathrm{F}_{\text {cal }} / \mathrm{F}_{\text {tab }}$ & PRESS \\
\hline 1 & $\mathrm{qC}_{10}, \mathrm{qC}_{12}, \mathrm{VOL}, \mathrm{MR}, \mathrm{MW}$ & 0.912 & 0.831 & 0.170 & 15.839 & 5.342 & 0.495 \\
\hline 2 & $\begin{array}{c}\mathrm{qC}_{10}, \mathrm{qC}_{12}, \mathrm{E} / \mathrm{HOMO}, \mathrm{SA}, \\
\mathrm{MR}, \mathrm{MW}\end{array}$ & 0.935 & 0.873 & 0.152 & 17.331 & 6.075 & 0.349 \\
\hline 3 & $\begin{array}{c}\mathrm{qC}_{2}, \mathrm{qC}_{8}, \mathrm{qC}_{10}, \mathrm{qC} \mathrm{C}_{12}, \mathrm{VOL}, \\
\mathrm{MR}, \mathrm{MW}\end{array}$ & 0.954 & 0.910 & 0.133 & 20.375 & 7.301 & 0.260 \\
\hline 4 & $\begin{array}{c}\mathrm{qC}_{4}, \mathrm{qC}_{6}, \mathrm{qC}_{8}, \mathrm{qC} \mathrm{C}_{10}, \mathrm{qC}_{12}, \mathrm{SA}, \\
\mathrm{MR}, \mathrm{MW}\end{array}$ & 0.959 & 0.920 & 0.130 & 18.798 & 6.800 & 0.249 \\
\hline
\end{tabular}

Table-3: Experimental and Predicted pIC $_{50}$ Value of the Test Set

\begin{tabular}{|c|c|c|c|c|c|}
\hline \multirow{2}{*}{$\begin{array}{c}\text { Test Set } \\
\text { Compound }\end{array}$} & \multirow{2}{*}{$\begin{array}{c}\text { Experimental } \\
\mathrm{pIC}_{50}\end{array}$} & \multicolumn{4}{|c|}{ Predicted $\mathrm{pIC}_{50}$} \\
\hline & & Model 1 & Model 2 & Model 3 & Model 4 \\
\hline 3 & 5.408 & 5.062 & 5.114 & 5.035 & 5.036 \\
\hline 9 & 5.000 & 4.760 & 4.761 & 4.764 & 4.733 \\
\hline 19 & 4.744 & 4.515 & 4.430 & 4.461 & 4.427 \\
\hline 25 & 5.045 & 4.712 & 4.878 & 4.692 & 4.729 \\
\hline 27 & 5.065 & 4.776 & 4.642 & 4.743 & 5.145 \\
\hline \multicolumn{2}{|c|}{ PRESS } & 0.424 & 0.449 & 0.503 & 0.416 \\
\hline \multicolumn{2}{|c|}{$\mathrm{r}^{2}$} & 0.975 & 0.862 & 0.959 & 0.593 \\
\hline \multicolumn{2}{|c|}{$\mathrm{r}_{\mathrm{m}}^{2}$} & 0.415 & 0.626 & 0.423 & 0.433 \\
\hline
\end{tabular}

Based on the best QSAR equation (model 2), increasing molecular weight (MW), surface area (SA), HOMO energy (E_HOMO), and net atomic charge on $\mathrm{C}_{10}\left(\mathrm{qC}_{10}\right)$ and $\mathrm{C}_{12}\left(\mathrm{qC}_{12}\right)$ would also increase antimalarial activity. However, increasing molar refractivity (MR) would decrease antimalarial activity. The higher value of net atomic charge on $\mathrm{C}_{10}$ and $\mathrm{C}_{12}$ could be obtained by the presence of electron-donating groups that could also increase the HOMO energy (E_HOMO) ${ }^{24}$ Electron-donating groups such as hydroxyl and methoxy could affect the HOMO energy of chalcone derivatives, and they play an important role in producing good antimalarial activity that would lead to the destruction and death of the parasite ${ }^{25-27}$ Based on QSAR analysis, several chalcones derivatives with electron-donating groups were proposed, and then they were synthesized via Claisen Schmidt reactions; the synthetic scheme is outlined in Fig.-1.<smiles>[R]c1ccc(C(C)=O)c(Br)c1</smiles>

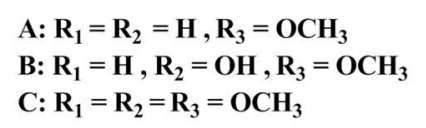

Fig.-1: The Synthesis Scheme of the Present Work

All the chalcones were characterized using IR, ${ }^{1} \mathrm{H}-\mathrm{NMR},{ }^{13} \mathrm{C}-\mathrm{NMR}$, and MS spectroscopies. Chalcones IR spectra depicted the existence of $\mathrm{C}_{\mathrm{sp} 2}-\mathrm{H}$ bending band at $979-997 \mathrm{~cm}^{-1}$, indicating the presence of transdisubstituted alkene and $1643-1658 \mathrm{~cm}^{-1}$ which is characteristic of $\mathrm{C}=\mathrm{O}$ of enone or $\alpha, \beta$-unsaturated ketone functional group. ${ }^{7}$ GC-MS spectra showed the molecular ion $\left(\mathrm{M}^{+}\right)$, which is related to the molecular weight of each chalcone. The ${ }^{1} \mathrm{H}-\mathrm{NMR}$ spectra of chalcones displayed two doublets with a coupling constants value $(J)$ of $15.0-15.55 \mathrm{~Hz}$, indicating the existence of trans coupling of alkene protons. ${ }^{25}$ In addition, the ${ }^{13} \mathrm{C}$ - 
NMR spectrum clearly showed the presence of an alkene carbon $\left(C_{\alpha}\right.$ and $\left.C_{\beta}\right)$ resonating at 119-120 and 143-144 ppm and carbonyl at 187-190 ppm for chalcone A-C. From all the evidence above, it can be concluded that all chalcones were successfully synthesized.

The synthesized chalcones were then assayed as antimalarial agents against $P$. falciparum 3D7 using microtechnique methods, and the result was presented in Table-5. It was shown that chalcones A-C have an $\mathrm{IC}_{50}$ value between 1-20 $\mu \mathrm{M}$, indicating that all of them were categorized as good antimalarial agents. ${ }^{13}$ From this table, the in vitro testing and QSAR analysis revealed that chalcone $\mathbf{C}$ had the highest antimalarial activity. This was due to chalcone $\mathbf{C}$ having three methoxy groups, which increased its surface area (SA), molecular weight (MW), and HOMO energy (E_HOMO). It showed that the lower value of $\mathrm{IC}_{50}$ from QSAR analysis would also give the lower $\mathrm{IC}_{50}$ from in vitro testing. The correlation $(\mathrm{r})$ of $\mathrm{IC}_{50}$ based on QSAR analysis and in vitro testing was found to be 0.858 . It indicated that the QSAR equation has a good trend in predicting antimalarial activity.

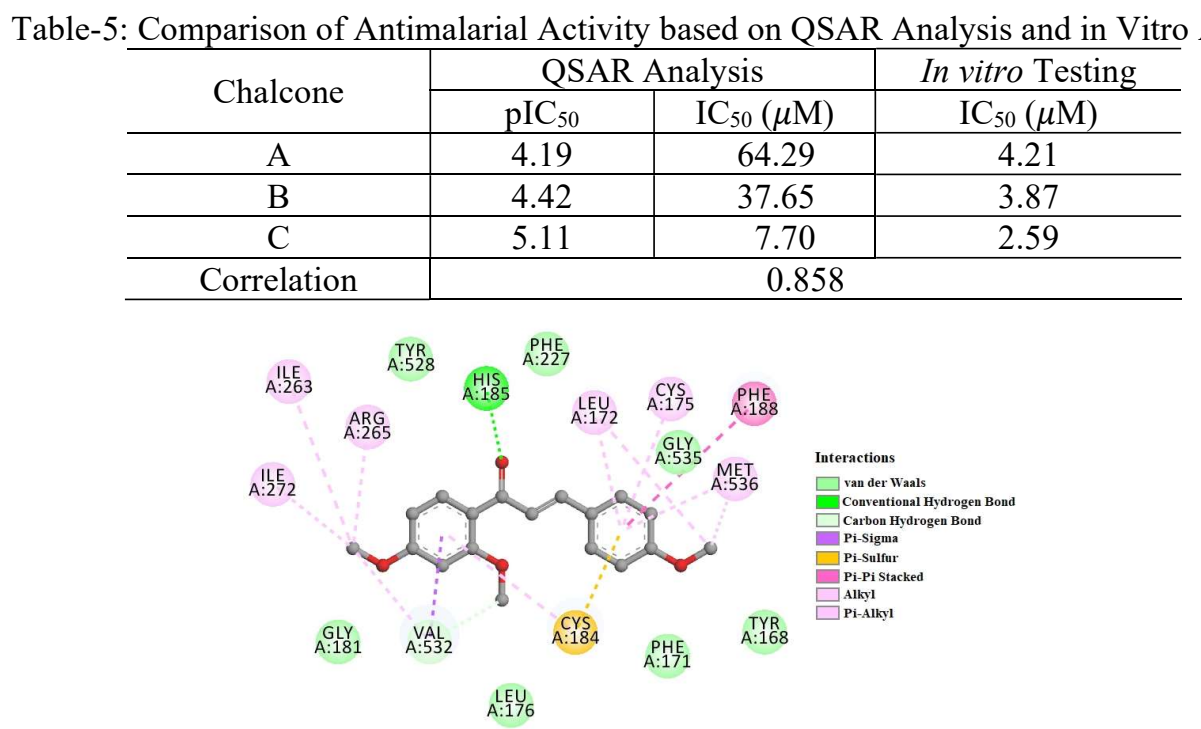

Fig.-2: Interaction of Chalcone $\mathbf{C}$ on the Active Site of PfDHODH

Molecular docking results showed that all designed chalcones interacted nicely with the active site of PfDHODH. These results showed that the binding affinity of chalcone $\mathbf{A}, \mathbf{B}$, and $\mathbf{C}$, was $-9.2,-8.9$, and $8.2 \mathrm{kcal} / \mathrm{mol}$, respectively, whereas the native ligand (inhibitor A26) was found to be $-9.0 \mathrm{kcal} / \mathrm{mol}$. This indicated that all chalcones could potentially inhibit the receptor. As shown in Fig.-2, chalcone $\mathbf{C}$ bound stably on important amino acid residues of Leu172, Phe171, Cys175, Gly181, Cys184, Phe188, Phe227, Ile263, Arg265, Tyr528, Val532, Gly535, and Met536, which play an important role in inhibiting PfDHODH. ${ }^{11}$

\section{CONCLUSION}

The QSAR analysis and synthesis of chalcone derivatives as an antimalarial compound towards $P$. falciparum 3D7 strain were carried out. The best and fitted QSAR equation is model 2, and it was used for designing some substituted chalcones to get a potential antimalarial agent. The synthesized chalcone derivatives with electron-donating groups were tested as an antimalarial agent against $P$. falciparum 3D7 strain, and the result showed that chalcone $\mathbf{C}$ with an $\mathrm{IC}_{50}$ value of $1.29 \mu \mathrm{M}$ has excellent activity as an antimalarial agent. Molecular docking results showed that chalcone $\mathbf{C}$ could be an inhibitor of PfDHODH potentially.

\section{ACKNOWLEDGEMENT}

The authors thank Universitas Gadjah Mada for financial support via Rekognisi Tugas Akhir (RTA) Project with contract No.: 3216/UN1/DITLIT/DIT-LIT/LT/2019. We also thank The Austrian Indonesian Centre for Computational Chemistry (AIC) for supplying the required facilities and software to conduct this research work. 
RASĀYAN J. Chem.

Vol. 14 | No. 4 |2363-2370| October- December | 2021

\section{REFERENCES}

1. R. Mueller, V. Reddy, A.T. Nchinda, F. Mebrahtu, D. Taylor, N. Lawrence, L. Tanner, M. Barnabe, C.J. Eyermann, B. Zou, R.R. Kondreddi, S.B. Lakshminarayana, M. Rottmann, L.J Street and K. Chibale, ACS Omega, 5(12), 6967(2020), http://dx.doi.org/10.1021/acsomega.0c00327

2. http://www.who.int/malaria/publications/world-malariareport2017/report/en/

3. K. Haldar, S. Bhattacharjee and I. Safeukui, Nature Reviews Microbiology, 16(3), 156(2018), http://dx.doi.org/10.1038/nrmicro.2017.161

4. V. Venkataramireddy, M. Shankaraiah, A. T. Rao, Ch. Kalyani, M. L. Narasu, R. Varala and A Jayashree, Rasayan Journal of Chemistry, 9(1), 31(2016)

5. C. Zhuang, W. Zhang, C. Sheng, W. Zhang, C. Xing and Z. Miao, Chemical Reviews, 117(12), 7762(2017), http://dx.doi.org/10.1021/acs.chemrev.7b00020

6. A. A. T. Suma, T. D. Wahyuningsih and Mustofa, Rasayan Journal of Chemistry, 12(2), 502 (2019), http://dx.doi.org/10.31788/RJC.2019.1225020

7. N. Sharma, D. Mohanakrishnan, U. K. Sharma, R. Kumar, Richa, A. K. Sinha and D. Sahal, European Journal of Medicinal Chemistry, 79, 350(2014), http://dx.doi.org/10.1016/j.ejmech.2014.03.079

8. J. Syahri, B. Purwono and R. Armunanto, International Journal of Pharmaceutical Sciences Review and Research, 36(2), 71(2016)

9. M. Flores-Sumoza, J. J. Alcázar, E. Márquez, J. R Mora, J. Lezama and E. Pulleo, Molecules, 23(12), 3166(2018), http://dx.doi.org/10.3390/molecules23123166

10. A. H. Abdelmonsef, M. E. Mohamed, M. El-Naggar, H. Temairk and A. M. Mosallam, Frontiers in Molecular Biosciences, 7(105), 1(2020), http://dx.doi.org/10.3389/fmolb.2020.00105

11. I.V. Singh and S. Mishra, American Journal of Biochemistry and Molecular Biology, 9(1), 1 (2019), http://dx.doi.org/10.3923/ajbmb.2019.1.6

12. Z. Y. Ibrahim, A. Uzairu, G. Shallangwa and S. Abechi, SN. Applied Sciences, 2(7), 1170(2020), http://dx.doi.org/10.1007/s42452-020-2955-1

13. R. Batista, A. de J. S. Júnior and A. B. de Oliveira, Molecules, 14(8), 3037(2009), http://dx.doi.org/ $10.3390 /$ molecules 14083037

14. M. J. Frisch, G. W. Trucks, H. B. Schlegel, G. E. Scuseria, M. A. Robb, J. R. Cheeseman, G. Scalmani, V. Barone, G. A. Petersson, H. Nakatsuji, X. Li, M. Caricato, A. V. Marenich, J. Bloino, B. G. Janesko, R. Gomperts, B. Mennucci, H. P. Hratchian, J. V. Ortiz, A. F. Izmaylov, J. L. Sonnenberg, D. WilliamsYoung, F. Ding, F. Lipparini, F. Egidi, J. Goings, B. Peng, A. Petrone, T. Henderson, D. Ranasinghe, V. G. Zakrzewski, J. Gao, N. Rega, G. Zheng, W. Liang, M. Hada, M. Ehara, K. Toyota, R. Fukuda, J. Hasegawa, M. Ishida, T. Nakajima, Y. Honda, O. Kitao, H. Nakai, T. Vreven, K. Throssell, J. A. Montgomery, Jr., J. E. Peralta, F. Ogliaro, M. J. Bearpark, J. J. Heyd, E. N. Brothers, K. N. Kudin, V. N. Staroverov, T. A. Keith, R. Kobayashi, J. Normand, K. Raghavachari, A. P. Rendell, J. C. Burant, S. S. Iyengar, J. Tomasi, M. Cossi, J. M. Millam, M. Klene, C. Adamo, R. Cammi, J. W. Ochterski, R. L. Martin, K. Morokuma, O. Farkas, J. B. Foresman, and D. J. Fox, Gaussian Inc., Wallingford CT. (2016)

15. HyperChem: HyperChem (TM), Professional 7.51, Hypercube, Inc. 1115 NW 4th Street, Gainesville, Florida 32601. USA. (2012)

16. D. B. De Oliveira and A. C. Gaudio, Quantitative Structure-Activity Relationships, 19(6), 599 (2000), http://dx.doi.org/10.1002/1521-3838(200012)19:6<599::AID-QSAR599>3.0.CO;2-B

17. R. Veerasamy, H. Rajak, A. Jain, S. Sivadasan, C. P. Varghese and R. K. Agrawal, International Journal of Drug Design and Discovery, 2(3), 511(2011)

18. K. H. Rieckmann, G. H. Campbell, L. J. Sax and J. E. Mrema, The Lancet, 311(8054), 22(1978), http://dx.doi.org/10.1016/s0140-6736(78)90365-3

19. Dassault Systèmes BIOVIA, Discovery Studio Modeling Environment, Release 2017, San Diego: Dassault Systèmes. (2016)

20. B. N. Diallo, T. Swart, H.C. Hoppe, Ö.T. Bishop and K. Lobb, Scientific Reports, 11(1413), 1 (2021), http://dx.doi.org/10.1038/s41598-020-80722-2

CHALCONE DERIVATIVES AS ANTIMALARIAL COMPOUND 
RASĀYAN J. Chem.

Vol. 14 | No. 4 |2363-2370| October- December | 2021

21. T. Khammee, A. Rattanapittayapron, C. Rangjaroen, A. Jaratrungtawee and M. Kuno, Rasayan Journal of Chemistry, 12(4), 2273(2019), http://dx.doi.org/10.31788/RJC.2019.1245412

22. W. L. DeLano, CCP4 Newsletter on Protein Crystallography, 40, 82(2002)

23. O. Trott and A. J. Olson, Journal of Computational Chemistry, 31(2), 455(2010), http://dx.doi.org/10.1002/jcc.21334

24. D. Gogoi, RNS. Yadav and P. Dutta, International Journal of Pharmaceutical Research and Application, 6(1), 190(2021), http://dx.doi.org/10.35629/7781-0601190202

25. J. Syahri, E. Yuanita, B. A. Nurohmah, R. Armunanto and B. Purwono, Asian Pacific Journal of Tropical Biomedicine, 7(8), 675(2017), http://dx.doi.org/10.1016/j.apjtb.2017.07.004

26. A. Batagin-Neto and F. C. Lavarda, Medicinal Chemistry Research, 23(2), 580(2014), http://dx.doi.org/10.1007/s00044-013-0667-4

27. K. Patel, C. Karthikeyan, N. S. H. N. Moorthy, G. S. Deora, V. R. Solomon, H. Lee and P. Trivedi, Medicinal Chemistry Research, 21(8), 1780(2012), http://dx.doi.org/10.1007/s00044-011-9694-1

[RJC-5867/2021] 